特に其反應の觀察に役立つ事が多い。

\title{
9. 結䨐
}

CP 合成ゴムの重合に屈折性質の變化を應用し、次の傾向を觀察し得た。

（1）自然重合には誘導期間が見られず、精溜直後より相虽活潑なる進行が示された。

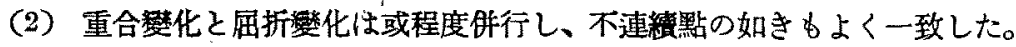

（3）波長範堛 6563〜 4358 ̊ で異常分散を示さず。且つ重合中の分散は大體一定してるた。

（4）比届折、比分散、屈折交點及び重合屈折は重合中一定の變化を示し、之により不飽和性の減少、分子 量の增加、重合の傾向を或程度伺び知ることが出來た。

（5）重合防止玮及び促淮劑に就て其效果を數字的に比較し得た。

（6）重合屈折の提案理由及び其意義に就き一言した。

（7）重合速度恒數を算出し、初期に於て其一次反應に從ふ事を知うた。

\section{再生ゴム使用電話屋外線に就いで}

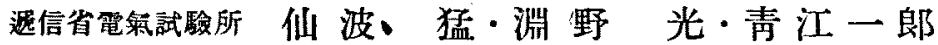

I. 緒言

ゴム被覆電線のゴム被覆は、良好なる絕線性、心線保䕶に必要なる機械的强度並にその使用目的に道應せる 柔軟性及び耐老化性等が要求せられる關係上、良質なる生ゴムを主體として製造せられて居り、技徾的にもこ れ等の要求を對象として研究、發達して來たものである。然るに今事戀による生ゴムの輸入制限、配給統制が 施行せられてより以來、ゴム被覆電線の製造に大なる支障を來たして居る。ゴム原料の一助として、直に使用 し得べき生ゴム代用品は、人造ゴム及び再生ゴムであるが、我國に於ける人造ゴム工業は未だこの方面にまで 使用し得る程度の生退力を有して居らぬのみならず、一般電線被覆材料の”主目的たる絕緣性及び機栈的性質に 缺點を有して居るものが多い。然しながら再生ゴムは、相當の生産高もあり、一般ゴム製品にあつては以前よ り各方面に多量、且廣範图に使用せられて居て、生ゴム代用品として現在最も普遍的なものであると考へられ る。殊に近時に於ては再生ゴムの憋造技術も次第に進步し、侲良なる製品が多量に生座せられて居る狀態であ る。然して大體生ゴムのみを主原料として發達せる我國のゴム被䠗電線製造工業に於ては再生ゴムの使用拔術 に就いて種々未知なる問題が存在して居るが、ここには生ゴム配合量節減の目的を以て試作せられた再生ゴム 使用ゴム被覆電線に就いて、電氣的、機械的及び人工老化試驗を行つた成績を報告するものである。份從來製 造せられて居た。生ゴムを原料とせる屋外ゴム線をす同樣なる試驗を行ひ研討の資料とした。

\section{II. 試料}

試料は遞信省指定某會社に於て試作せられたる再生ゴムを使用せる通信用二ケ撚編ゴム線 3 種類及び同一會 社製にして再生ゴムを含まざる電話屋外ゴム線である。通信用二ケ撚組ゴム線は、編組上の赤色及び黑色の塗 料にて區別され、素線は錫鋅僌銅線 $1.2 \mathrm{~mm}$ のものであり、被㢣ゴム詹は厚約 $1 \mathrm{~mm}$ を有して居た。その他 の萑成及び處理方法は從來製作せられたる條件と全く同一である。その被覆ゴムの成分は第 1 表に示す 3 種類

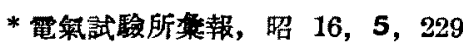


のものである。

第1表 被覆ゴムの成分（重量比）

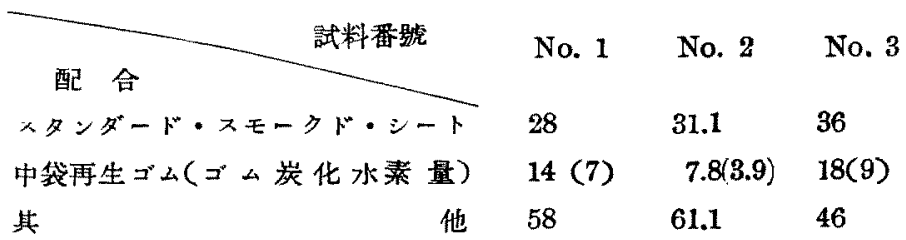

これ等 3 種の被䇯ゴムの配合は第

1 表に示す如くであり、再生ゴム のゴム炭化水素含有量を $50 \%$ と考 へろ時は、總ゴム炭化水素量が試料 No, 1 , No, 2 , に於て $35 \%$, No. 3 に於ては 45\% となる如く考慮せら

れた配合である。郎ち總ゴム炭化水素含有量の中で試料 No. 1 及び No. 3 とに於ては、その 20\%, No. 2 に 於ては、その $11.1 \%$ か洅生ゴム中のゴム炭化水秦によつて占められて居り、つまりそれだけ原料生ゴムが簛 粎されて居るわけである。

上記の配合にて製造せられたる試作品並に屋外ゴム線に就き化學分析を行ひたる結果、第2 表に示す數值を 得た。

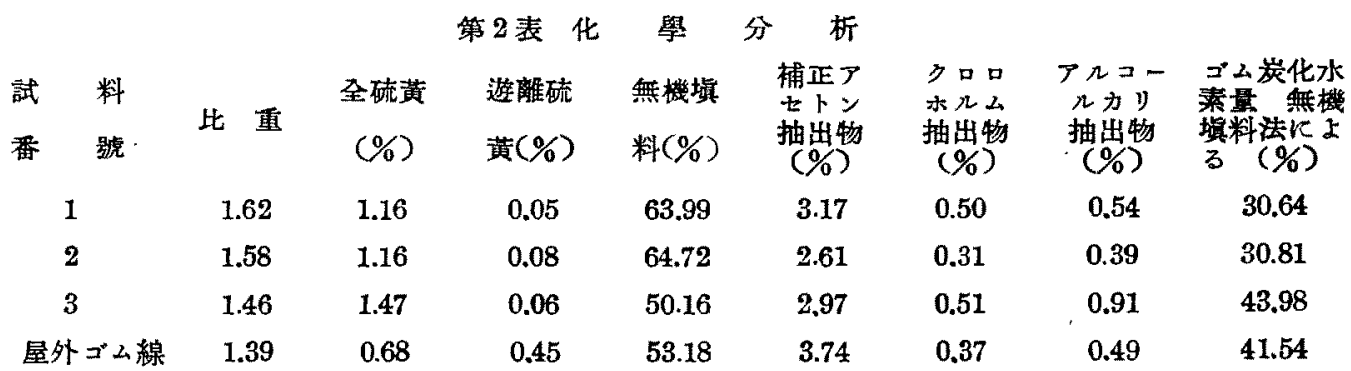

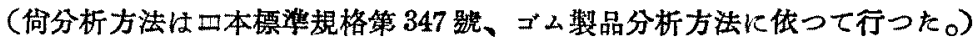

表に於て見る如く、再生ゴム使用電線のゴム炭化水素に對する結合䟽黄の比は試料 No. 3 が最も少い。分 析結果より判斷すれば、本試料作製に供せられた再生ゴムの炭化水素量は $50 \%$ に達して居なかつたと判镍せ られる。

\section{III. 察 驗 結 果}

\section{1. 電英的詿騷}

1、絕緣抵抗

1 試料の長さ $160 \mathrm{~m}$ のものを、21 時間水槽中に放置したる後、 $18.5^{\circ} \mathrm{C}$ にて直流 $100 \mathrm{~V}$ の電厓を 1 分間加 へ、各々心線對大地間の絕緣抵抗を測定した結果第 3 表の如くである。

\begin{tabular}{|c|c|c|c|c|}
\hline 試料番㒭 & No. 1 & No. 2 & No. 3 & 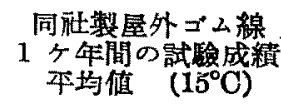 \\
\hline 绝稳担抗メダオーム & 5.470 & 8.850 & 9.200 & 7.110 \\
\hline
\end{tabular}

\section{口、縃緣破壊䉓废}

長さ $700 \mathrm{~mm}$ の試料に就き、その編組を取除き、中央部 $300 \mathrm{~mm}$ 間に錫䇴を經巻し、端效果を除き、錫箔 を一極として接地し、大氣中に於て心線と錫䇴間に 50 サイクル交流電晨を加へて試驗を行つた、5 包の湘定 值の平均は第 4 表の如くでする。 


\section{試料番號}

No. 1

No. 2

No. 3

屋外ゴム線

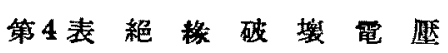

$\begin{array}{cc}\text { 心線直徑 }(\mathrm{mm}) & \text { 外 } \\ 1.20 & 2.76 \\ 1.21 & 2.98 \\ 1.20 & 3.03 \\ 1.20 & 3.10\end{array}$

破淁電磨 $(\mathrm{kV} / \mathrm{mm})$

20.1

19.2

25.9

27.6

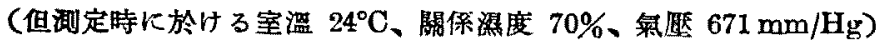

\section{八、交流特性}

再生ゴム使用電線試料の構成は前記の如く編組せるゴム線を撚合せたすのであり、現行の仕樣書による屋外 ごム楾は平打編租のもので、前者の如き構成を有するすのではなく、從つて交流特性を直接に比較する事は不 可能であるが、考的意味に於てその湘定結果を第 5 表に示す。向測定は編組のまま $10^{\circ} \mathrm{C}$ の大氣中に於て、 赤黑料相互間に就て行つた。

第5表 交 流 性 啠

\section{試毁頊目}

עーカンス $\mu \mathrm{mho} / \mathrm{km}$

容 電 量 $\mu \mathrm{F} / \mathrm{km}$

$G / C$
試料番䖓

No. 1

42.4

0.0505

840
No. 2

41.1

0.0484

848
No. 3

36.8

0.0472

779
屋外ゴム線

(220 $\mathrm{C}$ 火於て潮定)

28.0

0.0857

326

結果の考察

以上の電氣的結果より見るに試料 No. 1 及び No. 2 の比較、郎ちゴム炭化水素量の同一なる場合に於ては

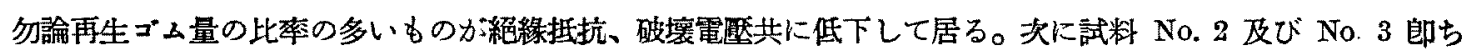
ゴム炭化水素總量も增加し再生ゴム配合率も亦增加した場合を考察するに、縃緣抵抗は再生ゴムによつて㧕制 され、生ゴム量を塻加しても餘り向上せず、それに反して破壞電血は炭化水素量の大なる程向上する樣であ る。要するに再生ゴムを以て生ゴムの一部を置換せるものは絶線抵抗、破壤電厚共に稍低下するが現用規格值 よりは滛汃に高值を示して居り、實用上何等篦念は無い。

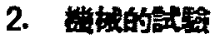

抗張力、及び永久伸

本試驗は遞信省に於て施行して居る電氣用品型式承認試驗の場合に準じて行つたもので、其の操作は次に詳

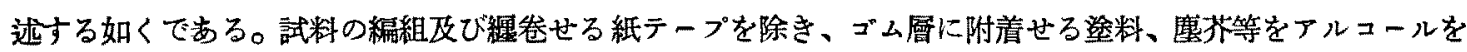
含も膯脂綿にてよく拭ひとり、常溫に於て充分乾燥せしめたる後、約 $120 \mathrm{~mm}$ の長さに心線を有するまま切 断し、ゴム層の切断面積をゴムの外俓と導體の外羿とより算出し、次に心線を拔きとり中央 $30 \mathrm{~mm}$ に標點を 附し、「ルイス・ショツハーーゴム抗張力試驗機の诚みの間隔を $50 \mathrm{~mm}$ となし、5 本の試料に就き測定し、そ の中の伸の大なるるの3本をとり、それら 3 測定值の平㚬を以て代表値とした。永久伸は前記試料の中央に 50 mm の標點を附し、これを $100 \mathrm{~mm}$ に延伸保持すること1分間の後放置し、10 分間後に於て测定せるもので

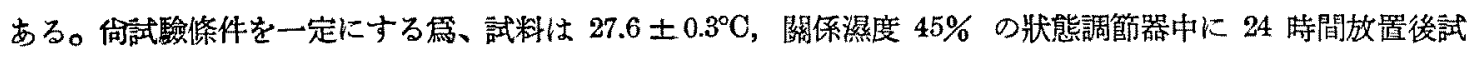
驗した。 
第 6 表 抗根力、伸及び永久伸

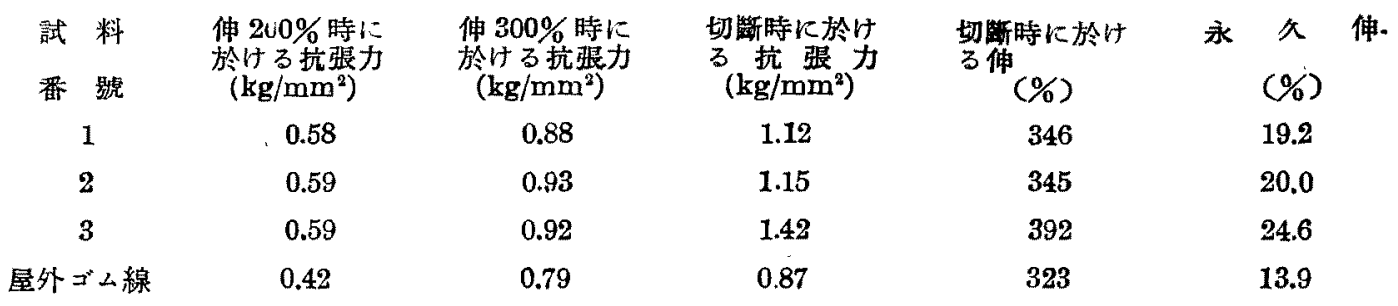

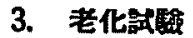

人工老化試驗に就いては一般に知られて居る方法 (1)のみにても數種をあげることが出來るが、如何なる方 法を選ぶベきかはその製品の使用目的によつて定る所である。本筫驗は單に生ゴム十再生ゴムによつて製作せ られたる被覆ゴムの老化性質を目的として調査せるもので、從つて老化方法も廣く一般に探用せられて居る高 臨酸素ボンブ法 (Bierer and Davis 法) (2) 加熱空氣法 (Geer 法) (3) 及 $130^{\circ} \mathrm{C}$ 加熱方法を探用した。

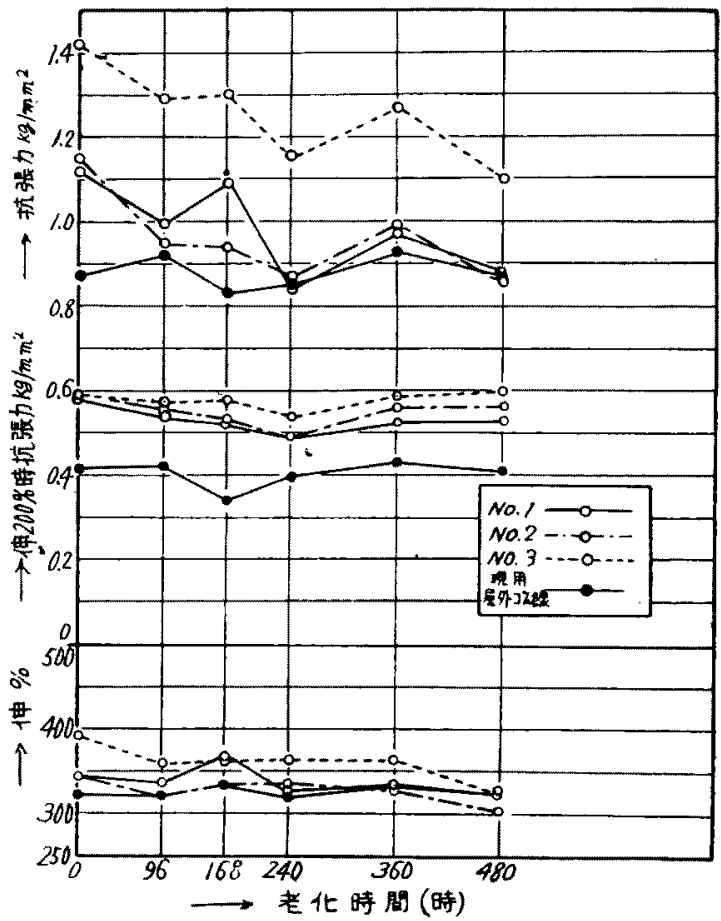

第 1 圆 嵪厴酸素ボンプ法による老化曲線 $\left(70^{\circ} \mathrm{C}\right)$

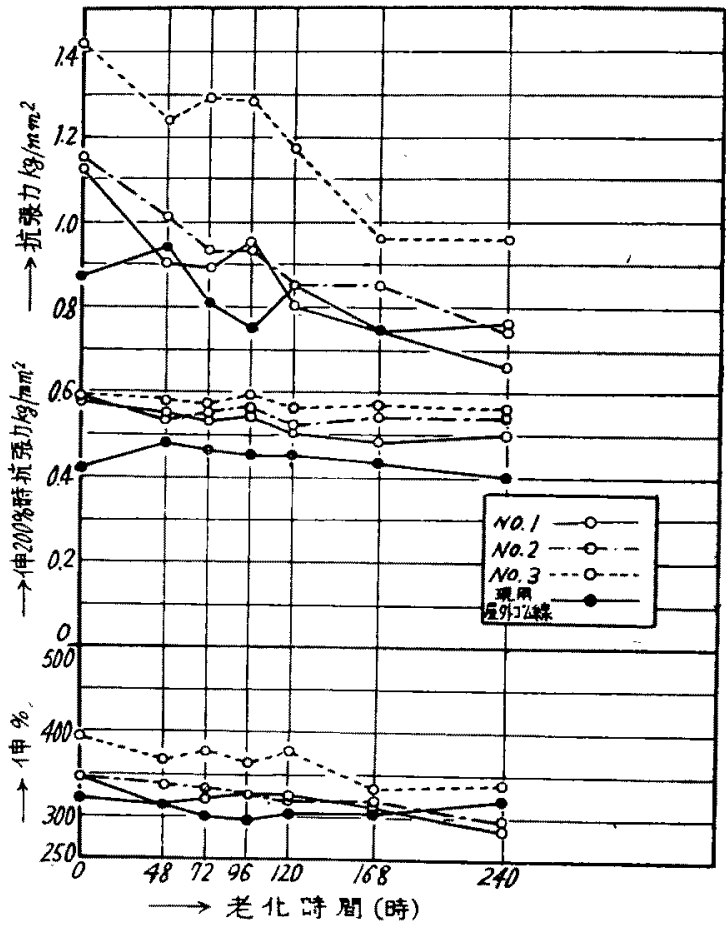

第 2 圆 加熱空氣法による老化曲線 $\left(70^{\circ} \mathrm{C}\right)$

第7表 高胆酸素ボンブ方法による老化試驗成績

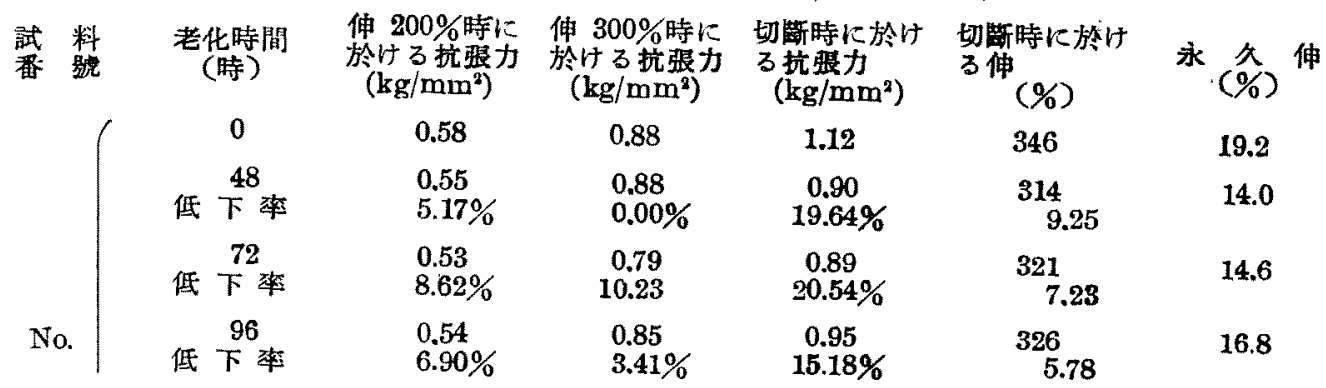




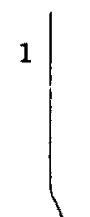

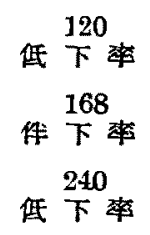

0.50

$13.79 \%$

0.72

$3.41 \%$

0.80

0.48

0.70

0.50

$13.79 \%$

$20.45 \%$

0.59

$\times$

No. \{

0

0.54

低下慗

$8.47 \%$

0.93

0.85

72

低下率

0.55

$6.78 \%$

8.60

0.56

低下率

$5.08 \%$

$0.83 \%$
$10.75 \%$

低 $\frac{120}{\text { 下率 }}$

0.52

$11.86 \%$

0.83

$10.75 \%$

0.54

0.78
$16.13 \%$

168

侮下淬

$8.47 \%$

低 $\frac{240}{下}$ 率

0.54

$8.47 \%$

$16.13 \%$

0.59

$18.28 \%$

$\times$

$\int$ 低

0
48

72

低穴率

No.

3

96

低下率

120

低下弶

0.58

$1.69 \%$

0.57

$3.39 \%$

0.59

$0.00 \%$

0.56

$5.08 \%$

0.92

0.91

$1.09 \%$

0.90

$2.17 \%$

0.94

168

低下泙

0.57

$3.39 \%$

$(+) 2.17 \%$

0.85

$7.61 \%$

$15.18 \%$

0.74

$33.93 \%$

0.66

$41.07 \%$

1.15

1.01

$12.17 \%$

0.93

$19.13 \%$

0.93

$19.13 \%$

0.85

$26.09 \%$

0.85

$26.09 \%$

0.74

$35.70 \%$

1.42

1.24

$12.68 \%$

1.29

$9.15 \%$

1.28

$9.86 \%$

1.17

$17.61 \%$

0.83

$9.76 \%$

0.96

$32.39 \%$

低 $\stackrel{240}{下}$ 率

0.56

0.83

$9.76 \%$

0.96

$32.39 \%$

0.41

0.79

0.87

0.44

0.82

48

$(+) 7.32 \%$

$(+) 3.80 \%$

0.94

低下亲

0.43

低卡势

$(+) 4.88 \%$

0.42

低穴菜

$(+) 2.44 \%$

0.76

$3.80 \%$

0.42

$x$

$(+) 8.05 \%$

0.77
$11.49 \%$

0.70

$19.54 \%$

0.81

低市率

$(+) 2.44 \%$

0.78

168

低下数

0.39

$4.88 \%$

0.66

$16.46 \%$

$6.90 \%$

0.68

$21.84 \%$

0.40
$2.44 \%$

0.67

0.79

$9.20 \%$

16.6

26.0

311

10.12

288

18.2

16.76

20.0

336

2.61

332

3.77

322

6.67

318

7.83

316

8.41

297

13.91

392

366

6.63

376

4.08

362
7.65

375

4.34

332

13.78

337

14.03

19.6

13.4

16.0

17.2

28.6

16.6

24.6

16.0

16.4

14.4

15.6

26.8

15.2

328

13.8

328

14.4

0.00

17.8

8.23

294

10.37

12.2

309

11.4

$15.19 \%$

5.79

14.2

7.32

314

4.27

12.8

何表中 $\times$ は試料の湖定不能になつたすのであり、(サ)は原值（抗張力及伸）に對し增加を示したるの で常識的意味にて與へた記號である。

\section{イ、高㻺酸素ボンブ方法による老化}

試料は前記機械的試驗に於て述べたる如く、編組を除き導體を拔かずにそのすを高壓酸素ボンブ裝置に納 め、70+1 $1^{\circ} \mathrm{C}, 20$ 氣厭の下にて $48,72,96,120,168,240$ の各特間老化せしめた。老化後直に狀態調節器中に於 て $27.6 \pm 0.3^{\circ} \mathrm{C}$, 關係濕度 $45 \%$.の下に 24 時間放置し、前記の如く抗㲀力、伸及び永久伸を測定した。結果 
は第 7 表、第 1 圖の如くで數值は既述の如く 5 本惯測せるものの中、伸の最高より 3 本をとり平均したるもの である。

第 8 表 加熱然氛方法による老化試驗成精

試 瞼 老化時)

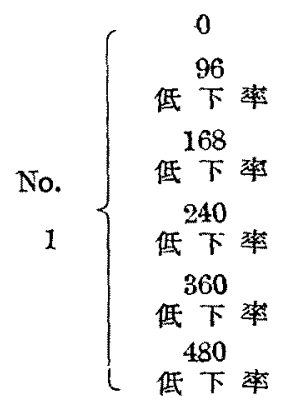

No.

0

低 $\frac{96}{\text { 索 }}$

低下乘

低下率

360

低下率

480

低下率

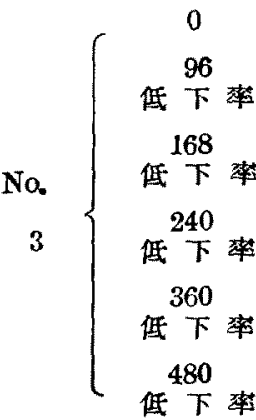

低下

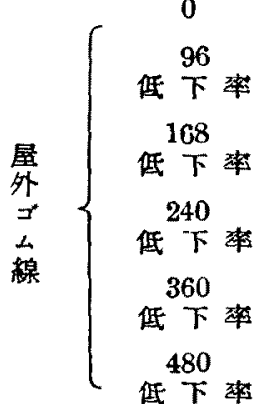
伸 $200 \%$ 時に $\left(\mathrm{kg} / \mathrm{mm}^{2}\right)$

0.58

$0.54 \%$
$6.90 \%$

0.52

$10.34 \%$

0.49

$15.52 \%$

0.53

$8.62 \%$

0.53

$8.62 \%$

0.59

0.56

$5.08 \%$

0.53

$10.17 \%$

049

$16.95 \%$

0.56

$5.08 \%$

0.56

$5.08 \%$

0.59

0.57

$3.39 \%$

0.58

$1.69 \%$

0.54

$8.47 \%$

0.59
$0.00 \%$

0.60
$(+) 1.69 \%$

0.41

0.41

$0.00 \%$

0.33

$19.51 \%$

0.40

$2.44 \%$

0.44

(t) $7.32 \%$

0.40
$2.44 \%$

伸 $300 \%$ 時飞

於ける抗张力

$\left(\mathrm{kg} / \mathrm{mm}^{2}\right)$

0.88
$0.84 \%$
$0.99 \%$
0.80
$9.09 \%$
0.73
$17.05 \%$
0.85
$3.41 \%$
080
$9.09 \%$

0.93

0.89

$4.30 \%$

0.81

$12.90 \%$

0.74

$20.43 \%$

0.84

$9.68 \%$

0.85

$8.60 \%$

0.92

0.96

$4.35 \%$

0.91

$1.09 \%$

0.79

$14.13 \%$

0.92

$0.00 \%$

1.00

$(+) 8.70 \%$

0.79

0.78

$1.27 \%$

0.64

$18.99 \%$

0.7 .3

$5.06 \%$

0.79

$0.00 \%$

0.75

$5.06 \%$
切获時に於け

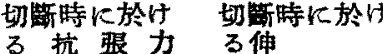

$\left(\mathrm{kg} / \mathrm{mm}^{2}\right)$ (\%)

1.12
$0.99 \%$
$11.61 \%$
1.09
$2.68 \%$
0.84
$25.00 \%$
0.97
$13.39 \%$
0.88
$21.43 \%$

1.15

0.95

$17.39 \%$

0.94

$18.26 \%$

0.87

$24.35 \%$

0.99

$13.91 \%$

0.86

$25.22 \%$

1.42

1.29

$9.15 \%$

1.30

$8.45 \%$

1.15

$19.01 \%$

1.27

$10.56 \%$

1.10

$22.54 \%$

0.87

0.87

$0.00 \%$

0.79

$9.20 \%$

0.88

$(+) 1.15 \%$

0.93

$(+) 6.90 \%$

0.87

$0.00 \%$
346

338

2.31

369

$(+) 6.65$

328

5.20

333

3.76

326

5.78

永久伸

(\%)

19.2

19.2

17.0

18.8

18.0

15.2

345

20.0

323

6.38

334

3.19

337

4.33

329

4.64

304

11.28

392

360

8.16

370

5.61

370

5.61

370

5.61

325

17.09

328

16.0

19.4

17.2

16.8

15.2

24.6

18.6

18.6

15.4

164

13.6

13.8

$318 \quad 12.8$

3.05

12.0

$(+) 0.61$

15.0

327

0.30

12.1

330
++50.61

325

12.4

口、加熱空氣方法による老化

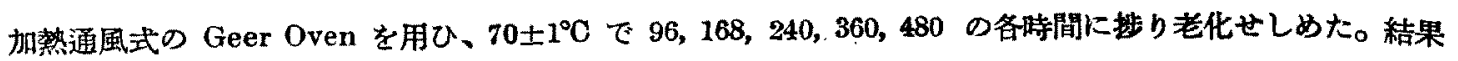


は第 8 表、第 2 圖の如くである。

八、130 ${ }^{\circ} \mathrm{C}$ 加熱方法に上る老化

本筫驗に於ても試料の取扱及び處理に就ては前 2 方法と全く同樣に行つたもので、裝置は geer 式の如く加 第 9 表 $130^{\circ} \mathrm{C}$ 加熱方法以上る老化試殷成續

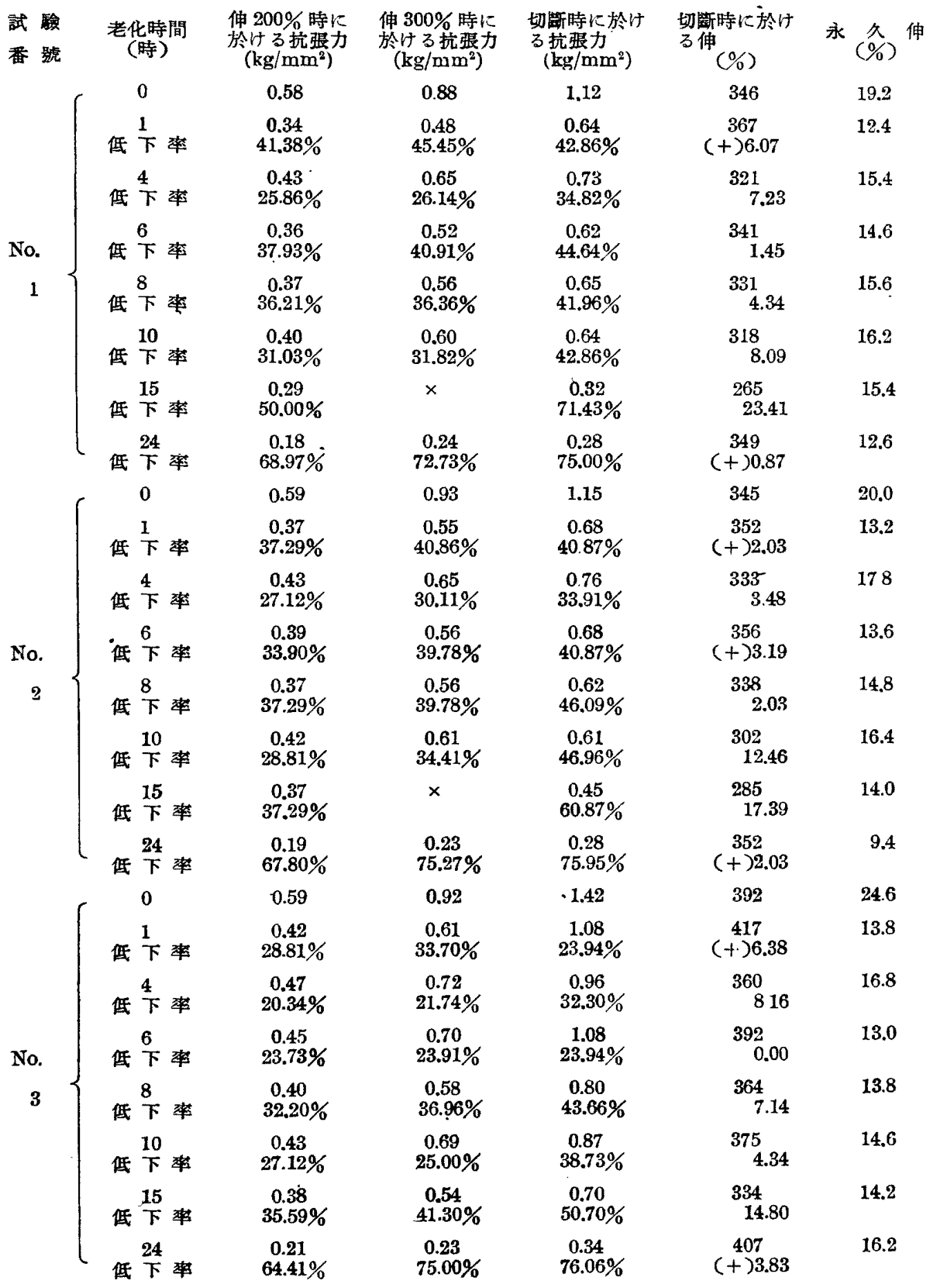


熱通風裝置を有しない通常の電熱乾燥器を使用し $130 \pm 2^{\circ} \mathrm{C}$ に於て、1, 4, 6, 8, 10,15, 24, の各時間老化せし めた。但屋外ゴム線は試料の都合上行はなかつた。結果は第 9 表、第 3 圆の如くである。

老化試驗結果の考察

先つ機械的試驗に於ける抗張力に就て見るに、比較の對象とせる屋外ゴム線が生ゴムを原料とせるるのであ りながら、再生ゴム使用笪線よりも小なる數值を示して居る。然しこれはこの屋外ゴム線がその分析值の示し て居る如く、遊離硫黄が比較的に大である事、郎ち未加硫狀態にあることに基くものと考へられる。從つて抗 張力の數值の小なる事は當然のことである。再生ゴム使用電線 3 試料に於ける抗張力はゴム量の大なる No. 3 が最高で、No.2 と No.1 に於ては再生ゴムの少、No 2 が稍高い值を示して居る。伸に於ては No.3 が最 大値を示して居ることはゴム量の大なる點より見て當然である。一體に永久伸の數值の大なることは再生ゴム 配合の現れであると思はれる。

老化試驗中、高是酸素ボンブ方法による 240 時間の老化に於て、抗張力の數值は屋外ゴム線にあつては幾分 未加硫でありながらも老化倾度に於て相當僬秀なる結果を示して居る。再生ゴム使用電線 3 試料に於ては、 ゴム量の大きい、No. 3 が最大で、No. 2, No. 1 の順序の强度を示した、然しその老化倾度を示す低下率を見

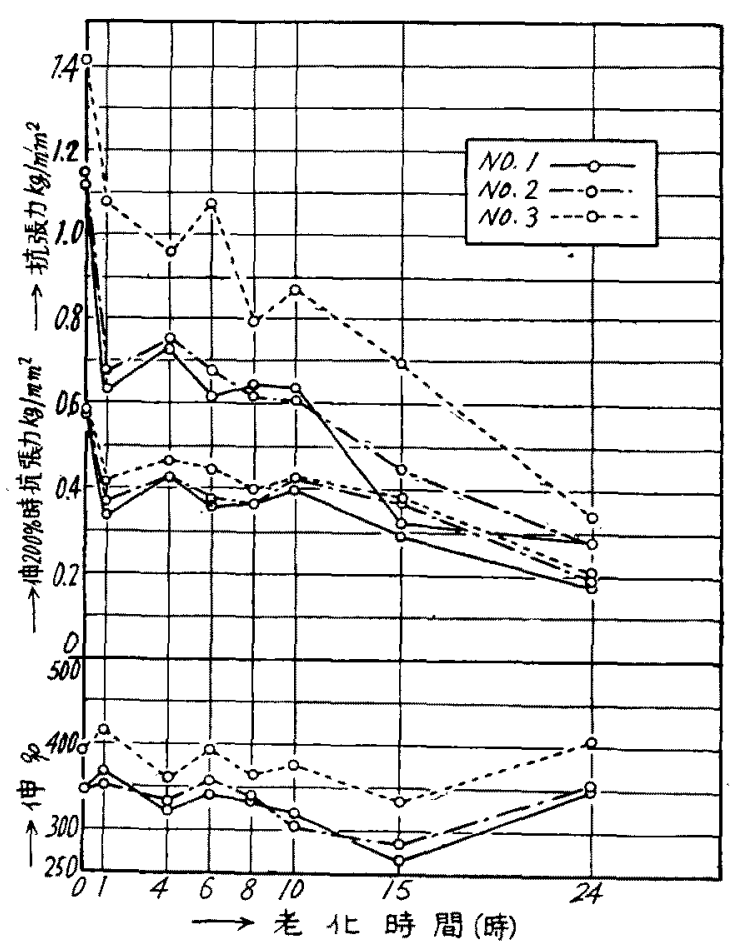

第 3 圆 $130^{\circ} \mathrm{C}$ 加熱による老化曲線 るには、他の三者より㒖に良好なるのみで大した差 は認められなかつたっこのことは $70^{\circ} \mathrm{C}$ 加熱空氣、480 時間老化に於ても同樣であり、老化後の抗張力の絕對 值は No. 3 が最も高く、No. 2, No. 1 の間には殆ど 差はなく老化傾度は 3 試料とも同一である。又屋外 厶線は老化傾度に於ては他の 3 試料に勝つて居る。光 に再生ゴム使用電線 3 試料の $130^{\circ} \mathrm{C}$ 加熱方法に於て は 8 時間老化邊りより、No. 3 の老化傾度は No.2 及 び No. 1 に次第に接近する傾向を示したが、然し 24 時間後に到つても纷幾分の差は認められた。再生ゴム 使用電線 3 試料の老化全體を通じて No. 2 と No. 1 に就ては、No. 2 が幾分高い數值を示して居り、これ は生ゴム對再生ゴムの配合比の影響と見られるが、低 下率に於ては上述の如く殆ど同程度であつた。伸に於 ては各老化共抗張力と大體平行したる關楅にあり、從 つて低下率も各試料間に大した差異は認められなかつ た。伸 $200 \%$ 及び $300 \%$ 時に於ける抗腲力が、No.3 を最大に、No. 1 の順序の强度を示して居ることは抗

張力の数値に平行して居り賞然のことである。

要するに老化試驗の成續に就いての考察は、ある時間後に於ける機械的强度の絕對值と、その老化傾度とを 作せて考へこれを生ゴムのみを原料として製造せられたる從來の製品の結果と比較考虑すべきである。然しこ の問題に就いては現在取䋥中の望驗もあり、他日發表の機會もあると思ふが、丁察且充分なる注意のもとに製 造せられたる、前記再生ゴム使用程度の配合比のものなれば老化倾向に關する限ら、在來の䌘品に比して大差 
なきすのと思ふ。機械的强度の點に關し老化前の原值は在来のののに比し大した低下を示して居らず、只老化 傾度に於て幾分低下して居る。この事望に從つても再生ゴムを使用するといふことは、その配合比に或る限度 の存在して居ることを示して居るが、電線の絶線被覆ゴムとして必要なる抗張力の最小限の值如何と言ふ點及 び各種再生ゴムの適當なる配合量等の問題に就いては改めて報告する预定である。

\section{IV. 要 約}

1. 再生ゴムを生ゴム皦約の一助として、生ゴムの一部に置換して製造せられたる 3 種の通信用 2 ケ撚編組 ゴム線の被覆ゴム(總ゴム炭化水素量同一にして、生ゴムと再生ゴムとの配合比を㜀じたるすの並に生ゴム及 び再生ゴムの量を僣加したるもの）及び同社彆現用屋外ゴム線の被临ゴムの分析を斷行し、その化學的組成を 明らかにした。

2. 3 種の編組 ゴム線及び同社慗現用屋外ゴム線の電氣的試驗を゙行ひたる結果、編組ゴム線の縃緣抵抗に於 ては、a. 總ゴム炭化水菜量同一なる場合は、再生ゴム量の多い方が低い值を示し、b、ゴム炭化水素量も增加 し、再生ゴム配合本も亦堵加せる場合、絕緣抵抗は再生ゴムに依つて抑制され、生ゴム量を聕加しても大して 向上しない。

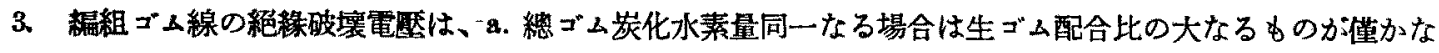
がら良好であり、總ゴム炭化水素量を增加する時は（再生ゴムをも亦僣加しても）破㙹電㕃は向上する。

4. 編組 ゴム線の機械的試驗に於てはゴム量の大なるものが、抗張力、伸共に良好であり、同一ゴム量の場 合には再生ゴムの配合量の大なる方が抗張力稍少るも、伸は同一である。

5. 各種人工老化試驗に於ける編組ゴム線間に於ては、ゴム岸化水素量の大なるものが、機械的强度高く、 ゴム炭化水素量の等しいものにあつては生ゴム配合比の大なるすのか潲良好な值を示した。然し老化傾度は 3 試料の間に差を認め得なかつた。現用屋外ごム線試料は未加硫のものながら老化傾度は良好であつた。

侗本報告中の電氣的試驗の一部は當部、岡本技手に御助力を願つたもので、こはに深く感謝の意を表する次 第である。

\section{引用女}

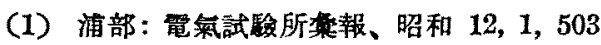

(2) J. W. Bierer and C. C. Davis. Ind. Eng. Chem, 1924, 16, 712

(3) W. C. Geer. I. R. W., 191655127

\section{錫めつき銅線のめつき試驗の檢討”}

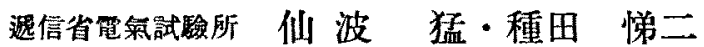

要旨 現在行はれてるる所の珁酸と多硫化ソーダ溶液に交互浸漬を繰返し、めつき表面に黑䙪の現れる迄の 處理回數を以て判定する錫めつき試驗法では、多硫化ソーダ液を調製する原料たる單硫化ソーダの品資の相違 によつて、純良なる標準薬品を用ひて試驗した場合に比して 2 倍に及ぶ搒驗結果の相違を來す場合がある。多 硫化ソーダ液の成分を稍禁更し郎ち硫黄を飽和する迄加へた液を用ひ且現行法よりも稍濃い泗酸を用ひる事に 